\title{
Inner-sphere Oxidation of Acetato- diaqua-(2- hydroxobenzy- lidene)- 5- phenylthiazol- 2- amino Cobalt (II) Complex by N-bromosuccinimide
}

\author{
A.E.M. Abdel-Hady ${ }^{\#}$, R.S. Farag* and A.S. Abu-Khadra* \\ Department of Pharmaceutical Chemistry,Faculty of Pharmacy, \\ Sinai University, Areesh City, P.O. Box 45518 and *Chemistry \\ Department, Faculty of Science, Al-Azhar University, Cairo, \\ Egypt.
}

\begin{abstract}
TINETICS oxidation of acetato- diaqua-(2-hydroxobenzylidene)5-phenylthiazol-2-amino cobalt (II) complex by Nbromosuccinimide (NBS) in aqueous media was studied spectrophotometrically over the $25-40{ }^{\mathrm{o}} \mathrm{C}$ range, $0.2-0.5 \mathrm{~mol} \mathrm{dm}$ ionic strength, and $\mathrm{pH}$ range (6.1-7.3) for a range of NBS and [complex]. The reaction rate was first order dependence on [NBS] and [complex] and increased with decreasing $\left[\mathrm{H}^{+}\right]$over the $\mathrm{pH}$ 's values. The experimental rate law was consistent with a mechanism in which the deprotonated form of the complex was considered as more reactive than its conjugate acid. Polymerization of acrylonitrile was taken as an evidence for the presence of free radical in the reaction mixture. It was assumed that electron transfer took place via an inner-sphere mechanism through the formation of the initial cobalt (III) products which were slowly converted to the final cobalt (III) products.
\end{abstract}

Keywords: Kinetics, Oxidation of cobalt (II) complex and Oxidation with N-bromosuccinimide.

$\mathrm{N}$-bromosuccinimide is a cheap and convenient oxidant which has been used for oxidation of some inorganic transition metal complexes ${ }^{(1-8)}$. The kinetics and mechanism of oxidation of a ternary complex involving dipicolinato-chromium (III) ${ }^{(1)}$ and DL-aspartic acid by N-bromosuccin- imide have been studied. The experimental rate law was consistent with a mechanism in which the deprotonated $\left[\mathrm{Cr}^{\mathrm{III}}(\mathrm{Dpc})(\mathrm{Asp})\left(\mathrm{H}_{2} \mathrm{O}\right)(\mathrm{OH})\right]^{-}$was considered to be the most reactive species compared to its conjugate acid. It was assumed that electron transfer took place via an inner-sphere mechanism. Kinetics and mechanism of oxidation of the binary and ternary complexes of chromium (III) involving inosine, $\left[\mathrm{Cr}(\mathrm{Ino})\left(\mathrm{H}_{2} \mathrm{O}\right)_{5}\right]^{3+}$, and glycine, $\left[\mathrm{Cr}(\mathrm{Gly})\left(\mathrm{H}_{2} \mathrm{O}\right)_{3}\right]^{2+}$ to $\mathrm{Cr}^{\mathrm{VI}}$ by $\mathrm{N}-$ bromosuccinimide in aqueous solutions were also studied spectrophotometrically over the $25-45{ }^{\circ} \mathrm{C}$ range ${ }^{(2)}$. The reaction was first order with respect to both [NBS] and $\left[\mathrm{Cr}^{\mathrm{III}}\right]$ in both cases. The hydroxo-complexes of chromium(III), $\left[\mathrm{Cr}(\mathrm{Ino})\left(\mathrm{H}_{2} \mathrm{O}\right)_{4}(\mathrm{OH})\right]^{2+}$ and $\left[\mathrm{Cr}(\mathrm{Ino})(\mathrm{Gly})\left(\mathrm{H}_{2} \mathrm{O}\right)_{2}(\mathrm{OH})\right]$, respectively were significantly more reactive than their conjugate acid. Furthermore, the kinetics of

\#Author of correspondence E-mail: alaaeldin60@yahoo.com

*Abstracted from M.Sc Thesis of Ahmad S. Abu-Khadra 
oxidation of ferrocyanide by (NBS) ${ }^{(3)}$ has been studied spectrophotometrically in aqueous acidic medium over temperature range $20-35^{\circ} \mathrm{C}, \mathrm{pH}=2.8-4.3$, and ionic strength $=0.10-0.50 \mathrm{~mol} \mathrm{dm}^{-3}$ over a range of $\left[\mathrm{Fe}^{2+}\right]$ and $[\mathrm{NBS}]$. The reaction exhibited first order dependence on both reactants and increased with $\mathrm{pH},[\mathrm{NBS}]$, and $\left[\mathrm{Fe}^{2+}\right]$. The rate of oxidation obeyed the rate law: $\mathrm{d}\left[\mathrm{Fe}^{3+}\right] / \mathrm{dt}=\left[\mathrm{Fe}(\mathrm{CN})_{6}\right]^{4}\left[\mathrm{HNBS}^{+}\right] /\left(\mathrm{k}_{2}+\mathrm{k}_{3} /\left[\mathrm{H}^{+}\right]\right)$. An outer-sphere mechanism has been proposed for the oxidation pathway of both protonated and deprotonated ferrocyanide species. Moreover, the kinetics of oxidation of (ethylenediaminediacetato)-chromium (III), $\left[\mathrm{Cr}(\mathrm{EDDA})\left(\mathrm{OH}_{2}\right)_{2}\right]^{+}{ }^{(4)}$ by(NBS) in aqueous solution to yield $\mathrm{Cr}^{\mathrm{VI}}$ has been studied spectrophotometrically over the $20-40^{\circ} \mathrm{C}$ range. The reaction rate was first order with respect to both [NBS] and $\left[\mathrm{Cr}^{\mathrm{III}}\right]$, and increased with $\mathrm{pH}$ over the range (4.8-5.8). A mechanism in which deprotonated, $\left[\mathrm{Cr}^{\mathrm{III}}(\mathrm{EDDA})\left(\mathrm{OH}_{2}\right)(\mathrm{OH})\right]$ was considered as the main reactive species was suggested. The electron transfer may proceed via an inner-sphere mechanism through bridging of the two reactants by the hydroxo-ligand. Additionally, inner-sphere oxidation of ternary imino -diacetato chromium (III) complex involving succinate ${ }^{(5)},\left[\mathrm{Cr}^{\mathrm{III}}(\mathrm{IDA})(\mathrm{Su})\left(\mathrm{H}_{2} \mathrm{O}\right],(\mathrm{IDA}=\right.$ iminodiacetate, $\mathrm{Su}=$ succinate) by NBS has been studied kinetically in aqueous solution over 25$45{ }^{\circ} \mathrm{C}$ and a variety of $\mathrm{pH}$ ranges. The rate of oxidation obeyed the equation $\mathrm{d}\left[\mathrm{Cr}^{\mathrm{VI}}\right] / \mathrm{dt}=\left\{\left[\mathrm{Fe}^{\mathrm{II}}\right]\left(\mathrm{k}_{5}+\mathrm{k}_{6} \mathrm{~K}_{1} /\left[\mathrm{H}^{+}\right]\right)+[\mathrm{NBS}]\left(\mathrm{k}_{7} \mathrm{~K}_{2}+\mathrm{k}_{8} \mathrm{~K}_{1} \mathrm{~K}_{3} /\left[\mathrm{H}^{+}\right]\right)\right\}\left[\mathrm{Cr}^{\mathrm{III}}\right](\mathrm{IDA})(\mathrm{Su})$ $\left.\left(\mathrm{H}_{2} \mathrm{O}\right)\right]^{-}$. The reaction was catalyzed by iron (II) and the catalysis is believed to be due to the oxidation of iron (II) to iron (III), which acted as the oxidizing agent. Also, the kinetics of oxidation of $\left[\mathrm{Co}^{\mathrm{II}} \mathrm{NM}\left(\mathrm{H}_{2} \mathrm{O}\right)\right]^{3-}{ }^{(6)}(\mathrm{N}=$ nitrilotriacetate , $\mathrm{M}=$ malonate) by (NBS) in aqueous solution has been found to obey the equation: $\mathrm{d}\left[\mathrm{Co}^{\mathrm{III}}\right] / \mathrm{dt}=\mathrm{k}_{1} \mathrm{~K}_{2}[\mathrm{NBS}]\left[\mathrm{Co}^{\mathrm{II}}\right]_{\mathrm{T}} /\left\{1+\mathrm{K}_{2}[\mathrm{NBS}]+\left(\mathrm{H}^{+} / \mathrm{K}_{1}\right)\right\}$ where $\mathrm{k}_{1}$ is the rate constant for the electron transfer process, $\mathrm{K}_{1}$, the equilibrium constant for dissociation of $\left[\mathrm{Co}^{\mathrm{II}} \mathrm{NM}\left(\mathrm{H}_{2} \mathrm{O}\right)\right]^{3-}$ to $\left[\mathrm{Co}^{\mathrm{II}} \mathrm{NM}(\mathrm{OH})\right]^{4-}+\mathrm{H}^{+}$, and $\mathrm{K}_{2}$, the preequilibrium formation constant. The kinetics of oxidation of $\left[\mathrm{Co}^{\mathrm{II}} \mathrm{NS}\left(\mathrm{H}_{2} \mathrm{O}\right)_{2}\right]^{(3-7)}$, $(\mathrm{N}=$ nitrilotriacetate, $\mathrm{S}=$ succinate) by (NBS) in aqueous solution has been studied spectrophotometrically in the $20-40{ }^{\circ} \mathrm{C}$ range. The reaction was first order each in [NBS] and $\left[\mathrm{Co}^{\mathrm{II}} \mathrm{NS}\left(\mathrm{H}_{2} \mathrm{O}\right)_{2}\right]^{3-}$, and the rate of reaction was increased with increasing $\mathrm{pH}$ between 6.64 and 7.73. The experimental rate law was consistent with a mechanism in which the deprotonated $\left[\mathrm{Co}^{\mathrm{II}} \mathrm{NS}\left(\mathrm{H}_{2} \mathrm{O}\right)(\mathrm{OH})\right]^{4-}$ was considered to be the most reactive species compared to its conjugate acid. It is assumed that electron transfer took place via an inner-sphere mechanism. The kinetics of the oxidation of the 2-aminomethylpyridine $\mathrm{Co}^{\mathrm{II}}$-complex ${ }^{(8)}$ by (NBS), has been studied in aqueous solutions under various conditions. An inner-sphere mechanism was proposed for the oxidation pathway for both protonated and deprotonated complex species, with the formation of an intermediate, which was slowly converted into the final oxidation products. The reaction rate was increased by increasing the $\mathrm{pH}$, temperature, [complex], and decreased by increasing ionic strength over the range studied.

The aim of this work was devoted to study the oxidation of $[\mathrm{Co}(\mathrm{L})$ (Ac) $\left.\left(\mathrm{H}_{2} \mathrm{O}\right)_{2}\right], \mathrm{L}=\mathrm{N}$-(2-hydroxobenzylidene)-5-phenylthiazol-2-amino, which acted as tridentate Schiff base, Ac = acetate, since the complex may be labile and the substitution of the coordinated water prior to the electron transfer is likely.

Egypt. J. Chem. 55, No.2 (2012) 


\section{Experimental}

\section{Materials and solutions}

All chemicals used in this study were of reagent grade and used without further purification. Double distilled water was used in all experiments and solutions preparations. Buffer solutions were prepared by mixing the appropriate volumes of $0.1 \mathrm{~mol} \mathrm{dm}^{-3}$ citric acid and $0.2 \mathrm{~mol} \mathrm{dm}^{-3} \mathrm{Na}_{2} \mathrm{HPO}_{4}$ for the required pH's. Solution of $\mathrm{NaCl}$ of known molarity was used to adjust the ionic strength in the different buffered used. Freshly prepared solution of complex and NBS were prepared daily by accurate weighing. A Schimadzu 1700 UV. Vis. spectrophotometer was used to follow the oxidation rate by monitoring the absorbance of the oxidation products at $\lambda=545-555 \mathrm{~nm}$, where the absorbance of Co(III) products were maximal at the $\mathrm{pH}$ 's used. The IR spectra were recorded using Perkin Elmer 57928. The pH of the reaction mixture was measured using 3505 Jenway pH-meter.

\section{Preparation of Schiff base}

$\mathrm{N}$-(2-hydroxobenzylidene)-5-phenylthiazol-2-amine Schiff base was prepared as reported ${ }^{(9)}$, by condensation of 2-amino-5-phenylthiazole) and salicylaldehyde in equimolar ratio for $1 / 2 \mathrm{hr}$ under reflux. The dark yellow precipitate was separated out by filtration, washed, recrystalized from EtOH and dried in disscator over an anhydrous $\mathrm{CaCl}_{2}$.

\section{Preparation of cobalt (II)-Schiff base complex}

Acetato-diaqua-(2-hydroxobenzy-lidene)-5-phenylthiazol-2-amino- cobalt (II) complex was prepared as reported ${ }^{(9)}$ by mixing $\mathrm{Co}\left(\mathrm{CH}_{3} \mathrm{COO}\right)_{2} \cdot 4 \mathrm{H}_{2} \mathrm{O}$, and the Schiff base in equimolar ratio (0.004) mole in $25 \mathrm{ml} \mathrm{EtOH}$. The reaction mixture was heated under reflux for $6 \mathrm{hr}$. The product was separated after cooling, by filtration, recrystallized from $\mathrm{EtOH}$ and dried to give the gray solid complex.

\section{Results and Discussion}

\section{IR spectra}

The IR spectrum of Schiff base exhibited a broad band at $3334 \mathrm{~cm}^{-1}$ assignable for the O-H bond, the bands at 3093 and $3096 \mathrm{~cm}^{-1}$ are characteristic for the stretching vibrations of $\mathrm{C}-\mathrm{H}$ aromatic bonds. The azomethine $\mathrm{C}-\mathrm{H}$ bond was presented by the bands at 2930 and $2825 \mathrm{~cm}^{-1}$. Meanwhile, the broad band at 3296 $\mathrm{cm}^{-1}$ was ascribed to the stretching mode of vibration of $\mathrm{NH}^{+}$generated by the Zewitter ion formation. The bands at 1602 and $1556 \mathrm{~cm}^{-1}$ were ascribed to the stretching mode of the azomethine bond, $\mathrm{C}=\mathrm{N}$, whereas, the bands at 1514 and $1470 \mathrm{~cm}^{-1}$ were accounted for the $\mathrm{C}=\mathrm{C}$ bond. The band at $1456 \mathrm{~cm}^{-1}$ was referred to the $\mathrm{C}-\mathrm{H}$ deformation bond. The $\mathrm{C}-\mathrm{N}$ bond was demonstrated by the bands at 1334 and $1336 \mathrm{~cm}^{-1}$ whereas the bands at 752 and $764 \mathrm{~cm}^{-1}$ were referred to the C$\mathrm{S}-\mathrm{C}$ bonds in the same respect. The elemental analysis of the Schiff base was: Found: C,67.8; H,4.56; N,9.23; S,11.50\%. $\mathrm{C}_{16} \mathrm{H}_{12} \mathrm{~N}_{2} \mathrm{OS}$ ( M.Wt. 280), Calcd; C,68.50; H.4.31; N,9.99; S, $11.4 \%$ and the melting point, $158-160{ }^{\circ} \mathrm{C}$. 
Electronic absorption spectra (UV-visible)

The electronic absorptions spectrum of the Schiff-base revealed the following results: $\lambda_{\max }=204-246,204-244 \mathrm{~nm}$ each region exhibits the phenyl ring transition $\left({ }^{1} \mathrm{~L}_{\mathrm{a}} \leftarrow{ }^{1} \mathrm{~A}\right)$, whereas the bands at 259 and $255 \mathrm{~nm}$ demonstrate the phenyl ring transition $\left({ }^{1} \mathrm{~L}_{\mathrm{b}} \leftarrow{ }^{1} \mathrm{~A}\right)$. The $\pi-\pi^{*}$ transitions of the $\mathrm{C}=\mathrm{N}$ group were displayed by $\lambda_{\max }=270 \mathrm{~nm}$. The broad peak at $\lambda_{\max }=331$ and $330 \mathrm{~nm}$, respectively, was referred to the $n-\pi^{*}$ transition of the azomethine group .

\section{${ }^{1}$ H NMR spectra}

The Schiff-base dissolved in DMSO-d6, was examined by ${ }^{1} \mathrm{H}$ NMR. The hydroxyl proton of the phenol was reported by a singlet at $\delta 11.6$ and $\delta 9$ which disappeared by the addition of $\mathrm{D}_{2} \mathrm{O}$. Within the range $\delta$ 6.8-7.8 the aromatic protons of the two different aromatic rings displayed multiplet signals. The azomethine proton was reported by a singlet at $\delta 7.86$.

Mass spectra (MS)

The mass spectra of the Schiff-base exhibited the following data : The molecular peak was respectively reported at $\mathrm{m} / \mathrm{e}=280(58.8 \%)$ and, $\mathrm{m} / \mathrm{e}=51$ $(13.9 \%)$. The compound also revealed the ion peak at $\mathrm{m} / \mathrm{e}=263(28.4 \%)$ for $\mathrm{M}^{+}\left(\mathrm{C}_{16} \mathrm{H}_{11} \mathrm{~N}_{2} \mathrm{~S}\right), \mathrm{m} / \mathrm{e}=247(57.7 \%)$ for $\mathrm{M}^{+}\left(\mathrm{C}_{16} \mathrm{H}_{11} \mathrm{~N}_{2} \mathrm{O}\right), \mathrm{m} / \mathrm{e}=203(16.5 \%)$ for $\mathrm{M}^{+}\left(\mathrm{C}_{10} \mathrm{H}_{7} \mathrm{~N}_{2} \mathrm{OS}\right), \mathrm{m} / \mathrm{e}=176(100 \%)$ for the base $\mathrm{M}^{+}\left(\mathrm{C}_{9} \mathrm{H}_{8} \mathrm{~N}_{2} \mathrm{~S}\right), \mathrm{m} / \mathrm{e}=134(73.9 \%)$ for $\mathrm{M}^{+}\left(\mathrm{C}_{8} \mathrm{H}_{6} \mathrm{~S}\right), \mathrm{m} / \mathrm{e}=102(62 \%)$ for $\mathrm{M}^{+}\left(\mathrm{C}_{8} \mathrm{H}_{6}\right), \mathrm{m} / \mathrm{e}=89(29.9 \%)$ for $\mathrm{M}^{+}\left(\mathrm{C}_{7} \mathrm{H}_{5}\right)$ and $\mathrm{m} / \mathrm{e}=77(33.3 \%)$ for $\mathrm{M}^{+}\left(\mathrm{C}_{6} \mathrm{H}_{5}\right)$. Furthermore, the ion peak at $\mathrm{m} / \mathrm{e}=102(7.4 \%)$ was assigned for $\mathrm{M}^{+}\left(\mathrm{C}_{8} \mathrm{H}_{5}\right)$, and $\mathrm{m} / \mathrm{e}=77(45.8 \%)$ for $\mathrm{M}^{+}\left(\mathrm{C}_{6} \mathrm{H}_{5}\right)$.

The collected data from the elemental and spectral analyses may illustrate the following structure of the Schiff base.

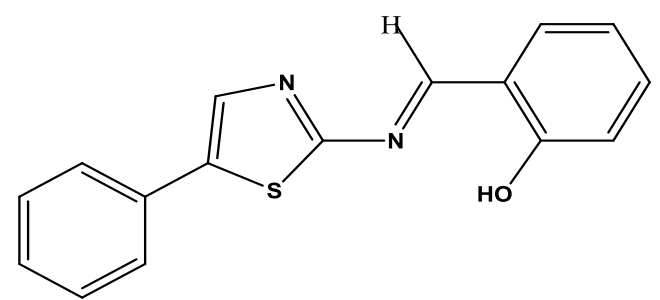

Elucidation of the metal-complex structure

The elemental analysis of the metal Schiff base complex was: Found: $\mathrm{C}, 49.43 ; \mathrm{H}, 4.01 ; \mathrm{N}, 6.27 ; \% . \mathrm{C}_{18} \mathrm{H}_{18} \mathrm{CoN}_{2} \mathrm{SO}_{5}$ Calcd; C,49.89; H,4.15; N, $6.46 ; \%$. The elemental analysis agrees with the formula, $\left[\mathrm{Co}(\mathrm{L})(\mathrm{Ac})\left(\mathrm{H}_{2} \mathrm{O}\right)_{2}\right]$ as reported ${ }^{(9)}$, where the ligand acts as monoionic tridentate giving an octahedral cobalt(II) complex.

IR spectra

In comparison with the parent ligand, common bands shift to lower or higher frequency with concomitant change in intensity observed. The weak broad band

Egypt. J. Chem. 55, No.2 (2012) 
at $3472 \mathrm{~cm}^{-1}$ was observed, which attributed to the stretching mode of vibration of the coordinated water molecules associated with the complex, the weak band observed at $3094 \mathrm{~cm}^{-1}$ can be attributed to the stretching mode of vibration of aromatic C-H. Further, the appearance of the band located at $1440 \mathrm{~cm}^{-1}$ can be assigned to the in-plane bending deformation mode of vibration of the aromatic $\mathrm{CH}$ bonds. Meanwhile, the $\mathrm{C}-\mathrm{H}$ aliphatic bond of the azomethine and the acetate group demonstrated weaker and lower shifted band located at $2934 \mathrm{~cm}^{-1}$. As incorporated in the coordination sphere, the azomethine bond exhibited shifts to lower frequencies, $1562 \mathrm{~cm}^{-1}$, which indicated that the nitrogen atom of the azomethine group participated in the coordination sphere. The acetate-group exhibited $v_{a s} \mathrm{COO}^{-}$that was indicated by the band at $1575 \mathrm{~cm}^{-1}$. In addition, the $v_{\text {sym }} \mathrm{COO}^{-}$was displayed by the band observed at $1344 \mathrm{~cm}^{-1}$. The C-S-C bonds revealed the band which appeared at $676 \mathrm{~cm}^{-1}$. The coordination bond $\mathrm{M} \leftarrow \mathrm{N}$ displayed the band at $616 \mathrm{~cm}^{-1}$. Furthermore, the $\mathrm{M} \leftarrow \mathrm{O}$ coordination bond demonstrated the band at $488 \mathrm{~cm}^{-1}$.

\section{$U V$-visible and magnetic behavior}

The electronic absorption spectrum of cobalt Schiff-base complex exhibited a band in the region 356-441 nm which corresponds to ${ }^{4} \mathrm{~T}_{1} \mathrm{~g} \rightarrow{ }^{4} \mathrm{~T}_{1} \mathrm{~g}(\mathrm{P})$ transition in the octahedral field supporting the octahedral for Co complexes, in addition to band in the regions, 202-245, 259, 271, 331nm corresponding to ${ }^{1} \mathrm{~L}_{\mathrm{a}} \leftarrow{ }^{1} \mathrm{~A},{ }^{1} \mathrm{~L}_{\mathrm{b}} \leftarrow$ ${ }^{1} \mathrm{~A}, \pi-\pi^{*}(\mathrm{C}=\mathrm{N})$ and $\mathrm{n}-\pi^{*}(\mathrm{C}=\mathrm{N}) \cdot \mathrm{d}-\mathrm{d}$ transitions exhibited bands at 376,403and $434 \mathrm{~nm}$.

The high-spin octahedral Co(II)-complex possesses three unpaired electrons, however, they may be distinguished by the magnitude of deviation of $\mu_{\text {eff }}$ from the spin-only value ${ }^{(10)}$. The measured magnetic moment, $\mu_{\text {eff }}=4.0-4.41$ B.M., shades light on the presence of three unpaired electrons indicating a high-spin octahedral configuration. This is supported by the band within the region $\lambda_{\max }=$ 356-441 nm representing the ${ }^{4} \mathrm{~T}_{1} \mathrm{~g} \rightarrow{ }^{4} \mathrm{~T}_{1} \mathrm{~g}(\mathrm{P})$ transitions.

In view of the above mentioned analyses the following conformation may be suggested for the metal-complex.

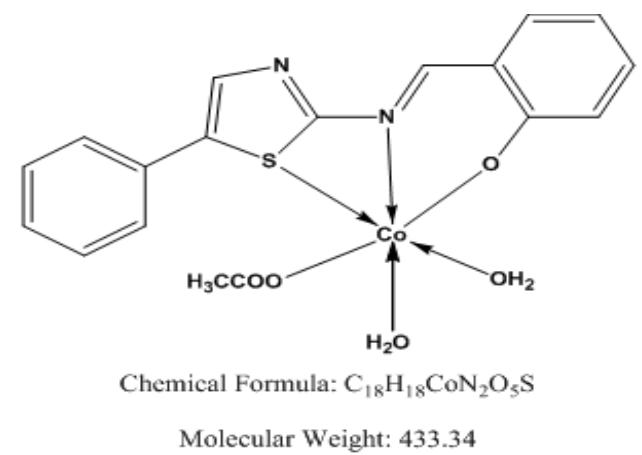

Egypt. J. Chem. 55, No.2 (2012) 
Antimicrobial activities

Acetato-diaqua-(2-hydroxobenzy-lidene)-5-phenylthiazol-2-amino cobalt (II) complex was tested for its antimicrobial activity using ampicillin as a reference compound technique ${ }^{(11)}$. The complex was dissolved in dimethyl sulfoxide (DMSO) $1 \mathrm{~g} / \mathrm{ml}$. The results obtained indicated that the complex has higher activity toward gram-positive bacteria like Bacillus subtilis (NCTC-1040); and higher to moderate activity for gram-negative bacteria like Clostridium and E. coli, respectively. Also, the complex was tested for its antifungal activity using Clofran as a reference compound; the results exihibited a higher activity for Aspergillus fungatus.

\section{Kinetic procedure}

NBS and Co(II)- complex solutions in the required buffers were allowed to equilibrate separately for ca. $20 \mathrm{~min}$ in water bath before the reaction was initiated and then thoroughly mixed and quickly transferred to an absorption cell where the absorbance of the oxidation products was measured for a definite period of time. Pseudo-first order conditions was applied in all kinetics runs by using a large (10 fold) excess of [NBS] over the [complex].

Kinetics of oxidation of $\left[\mathrm{Co}(\mathrm{L})(\mathrm{Ac})\left(\mathrm{H}_{2} \mathrm{O}\right)_{2}\right]$ by NBS was studied over $(6.10$ 7.30) $\mathrm{pH}$ range, $(0.20-0.50) \mathrm{mol} \mathrm{dm}^{-3}$ ionic strength and $20-40{ }^{\circ} \mathrm{C}$ for a range of the two reactants concentrations.

The absorbance of the oxidation products was measured immediately upon mixing of the two reactants and it was curved with time. Plots of $\ln \left(A_{\infty}-A_{t}\right)$ versus time were linear up to $\geq 80 \%$ of the reaction, where $A_{\infty}$ and $A_{t}$ are the absorbance of the oxidation products at infinity and at time $t$, respectively. The pseudo- first order rate constants, $\mathrm{k}_{\mathrm{obs}}$ were calculated from the slopes of the first order plots. The constancy of $\mathrm{k}_{\mathrm{obs}}$ values over the complex concentrations (1.03.0) $\times 10^{-4} \mathrm{~mol} \mathrm{dm}^{-3}$ as shown in (Table1) is in agreement with Equation 1.

$\mathrm{d}\left[\mathrm{Co}^{\mathrm{III}}\right] / \mathrm{dt}=\mathrm{k}_{\mathrm{obs}}\left[\mathrm{Co}^{\mathrm{II}}\right]_{\mathrm{T}}$

where $\left[\mathrm{Co}^{\mathrm{II}}\right]_{\mathrm{T}}$, represent the total concentration of $\mathrm{Co}^{\mathrm{II}}$-complex. The dependence of $\mathrm{k}_{\mathrm{obs}}$ on NBS was examined over $(0.5-3.0) \times 10^{-2} \mathrm{~mol} \mathrm{dm}^{-3}$ range. Kinetics data in Table 1 indicated that the rate of reaction increased as [NBS] increased. At constant temperatures, 1/ $\mathrm{k}_{\mathrm{obs}}$ varies linearly with 1/ [NBS] (Fig. 1) according to the equation $\mathrm{y}=\mathrm{mx}+\mathrm{c}$ and consistent with Equation 2 .

$1 / \mathrm{k}_{\mathrm{obs}}=1 / \mathrm{a}[\mathrm{NBS}]+\mathrm{b} / \mathrm{a}$

Egypt. J. Chem. 55, No.2 (2012) 
TABLE 1. Dependence of the reaction rate on $\left[\mathrm{Co}(\mathrm{L})(\mathrm{Ac})\left(\mathrm{H}_{2} \mathrm{O}\right)_{2}\right]$, [NBS] and temperatures at $\mathrm{pH}=6.1$ and $\mathrm{I}=0.20 \mathrm{~mol} \mathrm{dm}^{-3}$.

\begin{tabular}{ccc}
\hline $\begin{array}{c}\text { Temperature } \\
\left({ }^{\circ} \mathbf{C}\right)\end{array}$ & $\begin{array}{c}\mathbf{1 0}^{2}[\mathbf{N B S}] \\
\left(\mathbf{m o l ~ d ~}^{-3}\right)\end{array}$ & $\begin{array}{c}\mathbf{1 0}^{4} \mathbf{k}_{\text {obs }} \\
\left(\mathbf{s}^{-1}\right)\end{array}$ \\
\hline 25 & 1.0 & 7.87 \\
25 & 2.0 & 9.09 \\
25 & 3.0 & 9.73 \\
25 & 4.0 & 10.01 \\
25 & $2.0^{\mathrm{a}}$ & 9.15 \\
25 & $2.0^{\mathrm{b}}$ & 9.01 \\
25 & $2.0^{\mathrm{c}}$ & 9.18 \\
25 & $2.0^{\mathrm{d}}$ & 9.04 \\
30 & 1.0 & 9.54 \\
30 & 2.0 & 10.83 \\
30 & 3.0 & 11.52 \\
30 & 4.0 & 11.92 \\
35 & 1.0 & 11.84 \\
35 & 2.0 & 13.14 \\
35 & 3.0 & 13.70 \\
35 & 4.0 & 13.97 \\
40 & 1.0 & 14.53 \\
40 & 2.0 & 15.43 \\
40 & 3.0 & 15.92 \\
40 & 4.0 & 16.11 \\
\hline
\end{tabular}

Unless otherwise stated, $\left[\mathrm{Co}(\mathrm{L})(\mathrm{Ac})\left(\mathrm{H}_{2} \mathrm{O}\right)_{2}\right]=1.0 \times 10^{-4} \mathrm{~mol} \mathrm{dm}^{-3}$

${ }^{\mathrm{a}-\mathrm{d}}\left[\mathrm{Co}(\mathrm{L})(\mathrm{Ac})\left(\mathrm{H}_{2} \mathrm{O}\right)_{2}\right]$ was $1.5 \times 10^{-4} \mathrm{~mol} \mathrm{dm}^{-3}, 2.0 \times 10^{-4} \mathrm{~mol} \mathrm{dm}^{-3}$,

$2.5 \times 10^{-4} \mathrm{~mol} \mathrm{dm}^{-3}$ and $3.0 \times 10^{-4} \mathrm{~mol} \mathrm{dm}^{-3}$, respectively.

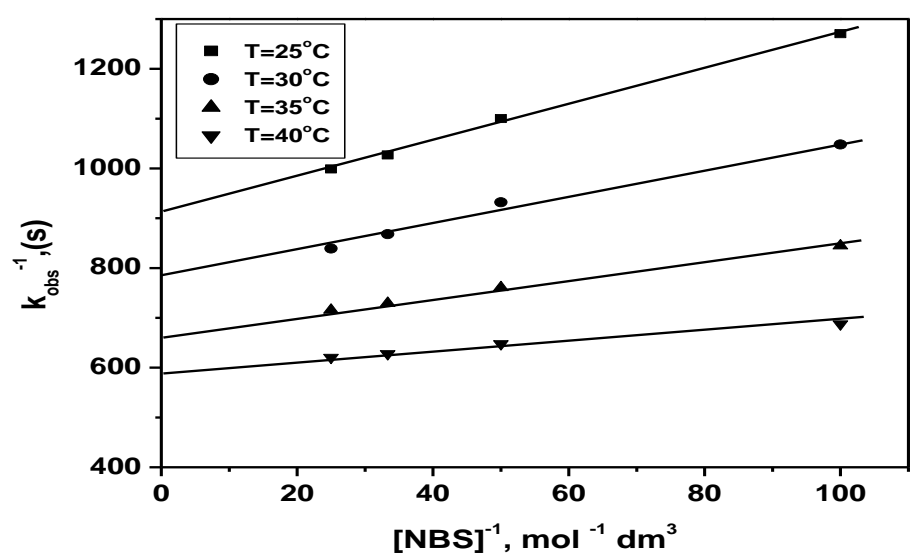

Fig. 1. Variation of $[\mathrm{NBS}]^{-1}$ with $\mathrm{k}_{\mathrm{obs}}{ }^{-1}$ values at different temperatures.

Egypt. J. Chem. 55, No.2 (2012) 
Values of $\mathrm{a}$ and $\mathrm{b}$ were calculated from the slopes and intercepts of the plots at different temperatures (Table 2). The effect of $\mathrm{pH}$ on the observed rate constant was studied by varying the $\mathrm{pH}$ values over the range (6.10-7.30) and keeping the other parameter constant. Values of $\mathrm{k}_{\mathrm{obs}}$ at different $\mathrm{pH}$ 's (Table 3) indicated that, the rate of the oxidation increased as the $\left[\mathrm{H}^{+}\right]$decreased over the range studied. This phenomenon supports the involvement of the deprotonated form of $\mathrm{Co}^{\mathrm{II}}$-complex in the rate determining step. Plots of $1 / \mathrm{k}_{\mathrm{obs}}$ versus $1 /[\mathrm{NBS}]$ at different $\mathrm{pH}$ 's (Fig. 2) were linear with definite intercept according to the equation $\mathrm{y}=\mathrm{mx}+\mathrm{c}$. Table 4 indicates that the reaction rate was independent on the ionic strength. This behavior is expected, as the product of the reactant's charges were zero. In highly acidic solution, NBS exist as protonated species $\mathrm{HNBS}^{+}$, but in our present work, the predominant species is NBS ${ }^{(12,13)}$. The observed kinetics for the oxidation of $\mathrm{Co}^{\mathrm{II}}$-complex by NBS under the experimental conditions may be described by the following reaction equations which include three fast pre-equilibria, followed by the rate determining steps.

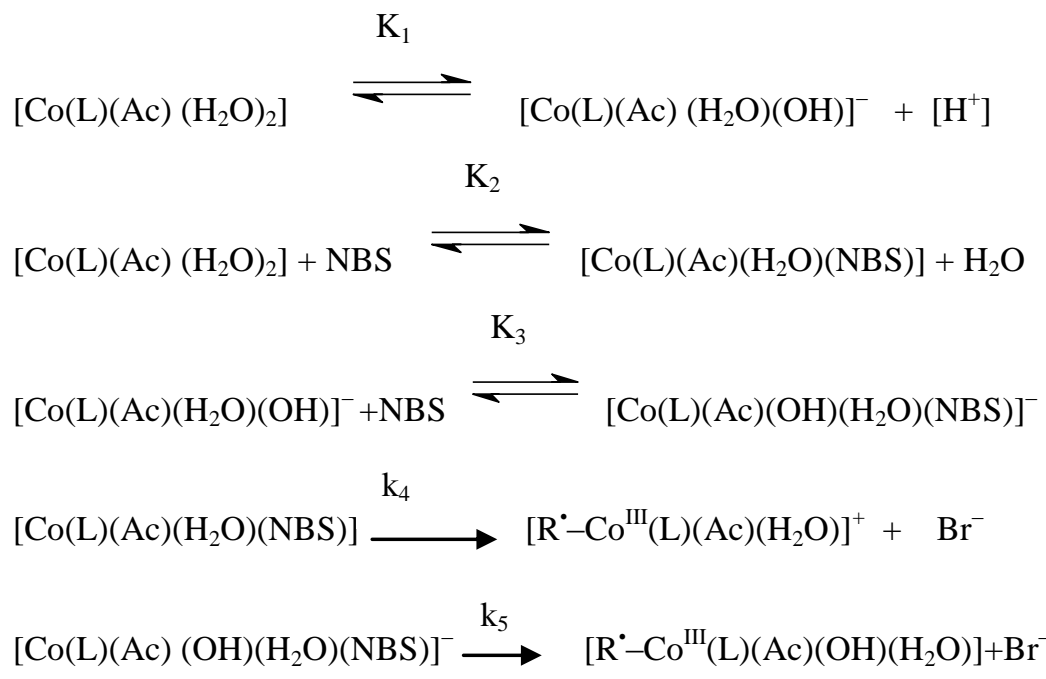

where $\mathrm{R}^{\cdot}$ is the succinimide radical. The $\mathrm{OH}^{-}$group for the species $\left[\mathrm{Co}(\mathrm{L})(\mathrm{Ac})(\mathrm{OH})\left(\mathrm{H}_{2} \mathrm{O}\right)(\mathrm{NBS})\right]^{-}$in Eq.(5) acts as labilise in $\mathrm{Co}^{-} \mathrm{OH}_{2}$ bond, surely the species cannot act as seven coordinate. From the above mechanism, the rate law is represented by,

$$
\begin{gathered}
\text { rate }=\mathrm{k}_{4}\left[\mathrm{Co}(\mathrm{L})(\mathrm{Ac})\left(\mathrm{H}_{2} \mathrm{O}\right)(\mathrm{NBS})\right]+\mathrm{k}_{5}\left[\mathrm{Co}(\mathrm{L})(\mathrm{Ac})(\mathrm{OH})\left(\mathrm{H}_{2} \mathrm{O}\right)(\mathrm{NBS})\right]^{-}= \\
{[\mathrm{NBS}]\left[\mathrm{Co}(\mathrm{L})(\mathrm{Ac})\left(\mathrm{H}_{2} \mathrm{O}\right)_{2}\right]\left\{\mathrm{K}_{2} \mathrm{k}_{4}+\mathrm{K}_{1} \mathrm{~K}_{3} \mathrm{k}_{5} /\left[\mathrm{H}^{+}\right]\right\}}
\end{gathered}
$$

If $[\mathrm{Co}]_{\mathrm{T}}$, represents all different forms of $\mathrm{Co}^{\mathrm{II}}$ species, then

$$
\begin{aligned}
& {\left[\mathrm{Co}^{\mathrm{II}}\right]_{\mathrm{T}}=\left[\mathrm{Co}(\mathrm{L})(\mathrm{Ac})\left(\mathrm{H}_{2} \mathrm{O}\right)_{2}\right]+\left[\mathrm{Co}(\mathrm{L})(\mathrm{Ac})\left(\mathrm{H}_{2} \mathrm{O}\right)(\mathrm{OH})\right]^{-}+\left[\mathrm{Co}(\mathrm{L})(\mathrm{Ac})\left(\mathrm{H}_{2} \mathrm{O}\right)\right.} \\
& (\mathrm{NBS})]+\left[\mathrm{Co}(\mathrm{L})(\mathrm{Ac})\left(\mathrm{H}_{2} \mathrm{O}\right)(\mathrm{OH})(\mathrm{NBS})\right]^{-}
\end{aligned}
$$

Egypt. J. Chem. 55, No.2 (2012) 
$\left[\mathrm{Co}(\mathrm{L})(\mathrm{Ac})\left(\mathrm{H}_{2} \mathrm{O}\right)_{2}\right]=\left[\mathrm{Co}^{\mathrm{II}}\right]_{\mathrm{T}} / 1+\mathrm{K}_{1} /[\mathrm{H}+]+[\mathrm{NBS}]\left\{\mathrm{K}_{2}+\mathrm{K}_{1} \mathrm{~K}_{3} /[\mathrm{H}+]\right\}$

Substitution from Eq. (9) into Eq. (8), then

rate $=[\mathrm{NBS}\}\left[\mathrm{Co}^{\mathrm{II}}\right]_{\mathrm{T}}\left\{\mathrm{K}_{2} \mathrm{k}_{4}+\mathrm{K}_{1} \mathrm{~K}_{3} \mathrm{k}_{5} /\left[\mathrm{H}^{+}\right]\right\} /\left\{1+\mathrm{K}_{1} /\left[\mathrm{H}^{+}\right]+[\mathrm{NBS}]\left\{\mathrm{K}_{2}+\right.\right.$ $\left.\left.\mathrm{K}_{1} \mathrm{~K}_{3} /[\mathrm{H}+]\right)\right\}$

$\mathrm{k}_{\mathrm{obs}}=[\mathrm{NBS}]\left\{\mathrm{K}_{2} \mathrm{k}_{4}+\mathrm{K}_{1} \mathrm{~K}_{3} \mathrm{k}_{5} /\left[\mathrm{H}^{+}\right]\right\} /\left\{1+\mathrm{K}_{1} /\left[\mathrm{H}^{+}\right]+[\mathrm{NBS}]\left(\mathrm{K}_{2}+\mathrm{K}_{1} \mathrm{~K}_{3} /\left[\mathrm{H}^{+}\right]\right)\right.$

The conjugate base of the complex, $\left[\mathrm{Co}(\mathrm{L})(\mathrm{Ac})\left(\mathrm{H}_{2} \mathrm{O}\right)(\mathrm{OH})\right]^{-}$is considered as more reactive species than its conjugate acid and the Eq. (11) is reduced to Eq.(12).

$\mathrm{k}_{\mathrm{obs}}=[\mathrm{NBS}]\left(\mathrm{K}_{1} \mathrm{~K}_{3} \mathrm{k}_{5} /\left[\mathrm{H}^{+}\right]\right) /\left\{1+\mathrm{K}_{1} /\left[\mathrm{H}^{+}\right]+[\mathrm{NBS}]\left(\mathrm{K}_{2}+\mathrm{K}_{1} \mathrm{~K}_{3} /\left[\mathrm{H}^{+}\right]\right)\right\}$

On rearrangement,

$1 / \mathrm{k}_{\mathrm{obs}}=\left(\left[\mathrm{H}^{+}\right]+\mathrm{K}_{1}\right) /[\mathrm{NBS}]\left(\mathrm{K}_{1} \mathrm{~K}_{3} \mathrm{k}_{5}\right)+\left(\mathrm{K}_{2}\left[\mathrm{H}^{+}\right]+\mathrm{K}_{1} \mathrm{~K}_{3}\right) / \mathrm{K}_{1} \mathrm{~K}_{3} \mathrm{k}_{5}$

At constant $\left[\mathrm{H}^{+}\right]$, Eq.(13) is consistent with Eq.(2), where

$\left.1 / \mathrm{a}=\left(\left[\mathrm{H}^{+}\right]+\mathrm{K}_{1}\right) / \mathrm{K}_{1} \mathrm{~K}_{3} \mathrm{k}_{5}\right)$ and

$\mathrm{b} / \mathrm{a}=\left(\mathrm{K}_{2}\left[\mathrm{H}^{+}\right]+\mathrm{K}_{1} \mathrm{~K}_{3}\right) / \mathrm{K}_{1} \mathrm{~K}_{3} \mathrm{~K}_{5}$

TABLE 2. Values of a and $b$ at different temperatures.

\begin{tabular}{ccc}
\hline $\mathbf{T}$ & $\begin{array}{c}\mathbf{a} \\
\left(\mathbf{m o l ~ d m}^{-\mathbf{3}}, \mathbf{s}^{-\mathbf{1}}\right)\end{array}$ & $\begin{array}{c}\mathbf{b} \\
\left(\mathbf{~ m o l ~ d m}^{\mathbf{0}}\right)\end{array}$ \\
\hline & & \\
25 & 0.275 & 250 \\
30 & 0.364 & 282 \\
35 & 0.581 & 391 \\
40 & 1.110 & 665 \\
\hline
\end{tabular}

TABLE 3. Effect of pH on $\mathrm{k}_{\text {obs }}\left(\mathrm{s}^{-1}\right)$ at $\left[\mathrm{Co}(\mathrm{L})(\mathrm{Ac})\left(\mathrm{H}_{2} \mathrm{O}\right)_{2}\right]=1.0 \times 10^{-4} \mathrm{~mol} \mathrm{dm}^{-3}, \mathrm{I}=0.20$ mol dm ${ }^{-3}$, and $\mathrm{T}=25^{\circ} \mathrm{C}$.

\begin{tabular}{ccccc}
\hline $\mathbf{1 0}^{\mathbf{4}}[\mathbf{N B S}], \mathbf{~ m o l ~ d m}^{-\mathbf{3}}$ & $\mathbf{p H = 6 . 1 0}$ & $\begin{array}{c}\mathbf{1 0}^{\mathbf{4}} \mathbf{k}_{\mathbf{o b s}}\left(\mathbf{s}^{\mathbf{- 1}}\right) \\
\mathbf{p H = 6 . 5 0}\end{array}$ & $\mathbf{p H = 6 . 9 0}$ & $\mathbf{p H = 7 . 3 0}$ \\
\hline 1.0 & 7.87 & 11.02 & 12.73 & 14.28 \\
2.0 & 9.09 & 12.78 & 13.80 & 15.70 \\
3.0 & 9.73 & 13.20 & 14.41 & 15.90 \\
4.0 & 10.01 & 13.46 & 14.73 & 16.09 \\
\hline & & & Egypt. J. Chem. 55, No.2 (2012)
\end{tabular}


TABLE 4. Effect of ionic strength on the reaction rate at $\left[\mathrm{Co}(\mathrm{L})(\mathrm{Ac})\left(\mathrm{H}_{2} \mathrm{O}\right)_{2}\right]=1.0 \times 10^{-4}$ $\mathrm{mol} \mathrm{dm}{ }^{-3}, \mathrm{pH}=6.10,[\mathrm{NBS}]=0.02 \mathrm{~mol} \mathrm{dm}^{-3}$, and $\mathrm{T}=25^{\circ} \mathrm{C}$.

\begin{tabular}{|c|c|}
\hline $\begin{array}{c}\mathbf{I} \\
\left(\mathbf{m o l ~ d m}^{-3}\right)\end{array}$ & $\begin{array}{c}\mathbf{1 0}^{\mathbf{4}} \mathbf{k}_{\text {obs }} \\
\left(\mathbf{s}^{-\mathbf{1}}\right)\end{array}$ \\
\hline 0.20 & 9.09 \\
0.30 & 9.15 \\
0.40 & 9.07 \\
0.50 & 9.20 \\
\hline
\end{tabular}

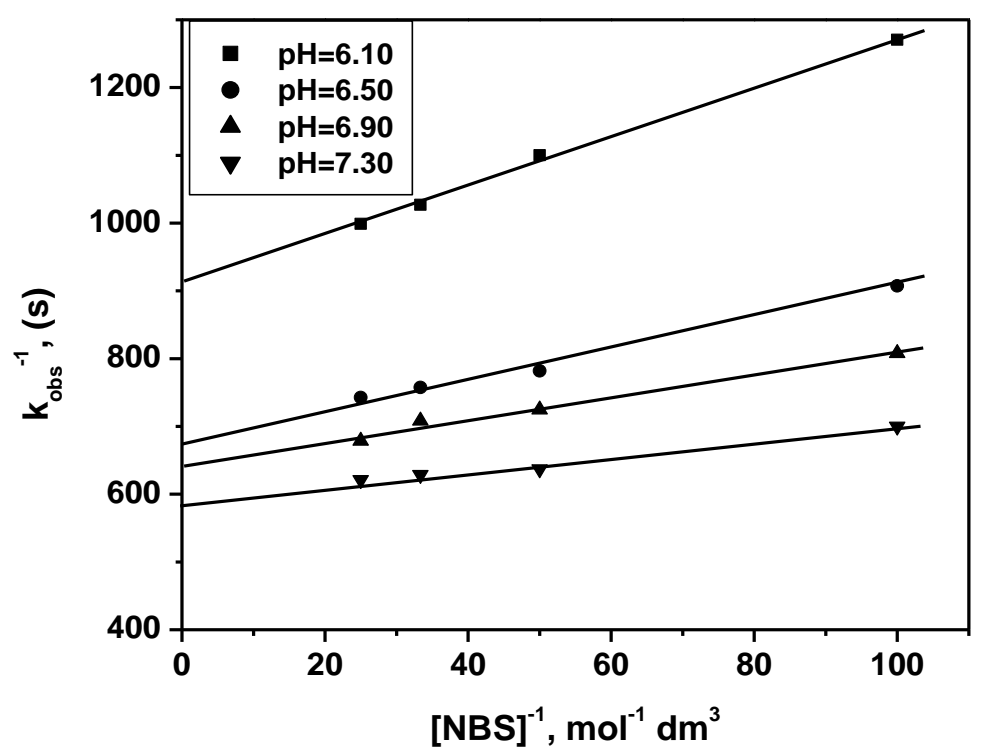

Fig. 2. Variation of $[\mathrm{NBS}]^{-1}$ with $\mathrm{k}_{\mathrm{obs}}{ }^{-1}$ values at different $\mathrm{pH}$ 's.

Plot of 1/a versus $\left[\mathrm{H}^{+}\right]$was linear with correlation coefficient $=.99032$ (Fig.3) with slope $=3.24$ which equals to $1 / \mathrm{K}_{1} \mathrm{~K}_{3} \mathrm{~K}_{5}$ and intercept $=1.09$ which equals to $1 / \mathrm{K}_{3} \mathrm{k}_{5} . \mathrm{K}_{1}$ was calculated by dividing the intercept by the slope of the plot as $0.3364 \mathrm{~mol}^{-1} \mathrm{dm}^{3}$. Plot of b/a versus $\left[\mathrm{H}^{+}\right]$was also linear with correlation coefficient $=0.99186$ (Fig.4) with slope $=4.17$ corresponds to $\mathrm{K}_{2} / \mathrm{K}_{1} \mathrm{~K}_{3} \mathrm{k}_{5}$ and intercept $=572.95$ corresponds to $1 / \mathrm{k}_{5}$. $\mathrm{k}_{5}$ was calculated from the reciprocal of the intercept of the a / b versus $\left[\mathrm{H}^{+}\right]$plot as $1.74 \times 10^{-3} \mathrm{~mol}^{-1} \mathrm{dm}^{3}, \mathrm{~s}^{-1} \cdot \mathrm{K}_{2}$ was calculated by dividing the slope of a / b versus $\left[\mathrm{H}^{+}\right]$by the slope of $1 / \mathrm{a}$ versus $\left[\mathrm{H}^{+}\right]$ plots as $1.28 \mathrm{~mol} \mathrm{dm}^{-3}$. Substituting the value $\mathrm{k}_{5}$, one can get the value of $\mathrm{K}_{3}$ from the intercept of $1 / \mathrm{a}$ versus $\left[\mathrm{H}^{+}\right]$plot as $527.42 \mathrm{~mol}^{-1} \mathrm{dm}^{3}$. Thermodynamic activation parameters including $\Delta \mathrm{H}^{*}$ and $\Delta \mathrm{S}^{\star}$ associated with the constant a in Eq. (2) were calculated using a least square fit to the transition state theory equation as $69.1 \mathrm{~K} \mathrm{~J} \mathrm{~mol}^{-1}$ and $-24.6 \mathrm{JK}^{-1} \mathrm{~mol}^{-1}$, respectively. $\Delta \mathrm{H}^{*}$ is a composite value including the enthalpy of formation associated with the precursor complex $\left[\mathrm{Co}(\mathrm{L})(\mathrm{Ac})\left(\mathrm{H}_{2} \mathrm{O}\right)(\mathrm{OH})\right]^{-}$and the enthalpy of activation of the intramolecular 
electron transfer step. The electron transfer step is endothermic as indicated by the positive value of $\Delta \mathrm{H}^{*}$. The composite negative value of $\Delta \mathrm{S}^{\ddagger}$ was claimed to be largely the result of substantial ordering of the solvated water molecules ${ }^{(14)}$ of both equilibrium reactions and intramolecular electron transfer step.

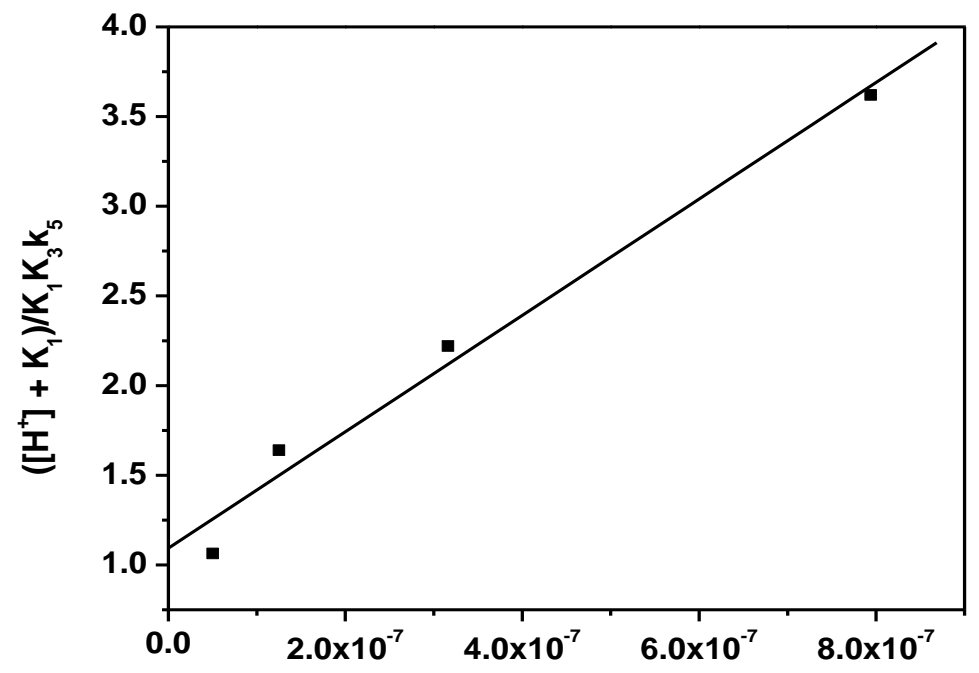

$\left[\mathrm{H}^{+}\right], \mathrm{mol} \mathrm{dm}^{-3}$

Fig. 3. Variation of $\left.\left(\left[\mathbf{H}^{+}\right]+\mathbf{K}_{1}\right) / \mathbf{K}_{1} \mathbf{K}_{3} \mathbf{k}_{5}\right)$ with $\left[\mathbf{H}^{+}\right]$.

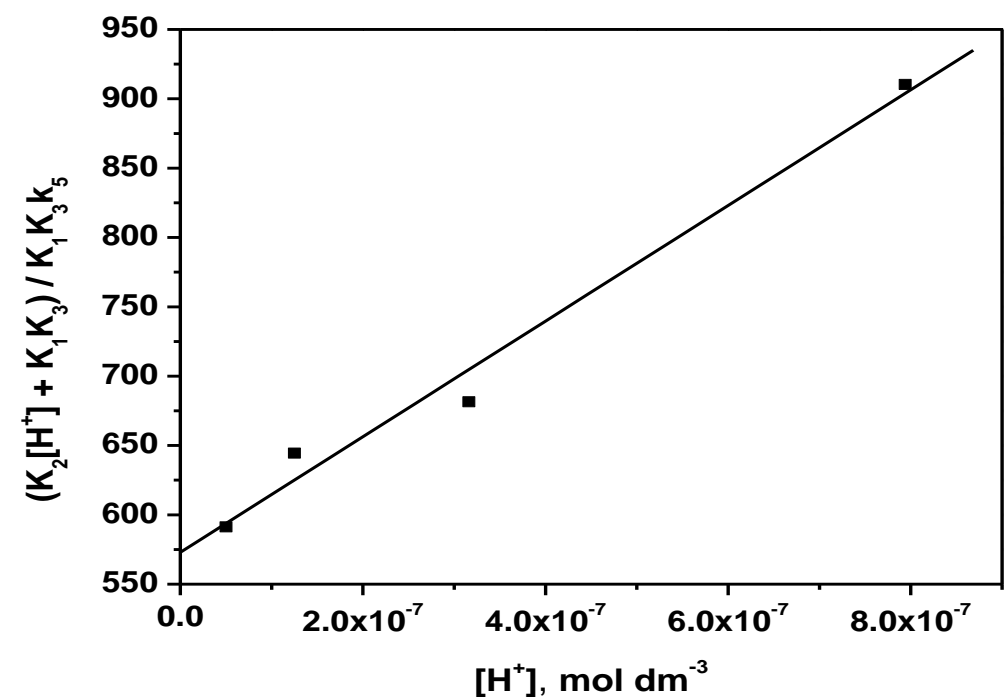

Fig. 4. Variation of $\left(\mathrm{K}_{2}\left[\mathrm{H}^{+}\right]+\mathrm{K}_{1} \mathrm{~K}_{3}\right) / \mathrm{K}_{1} \mathrm{~K}_{3} \mathrm{k}_{5}$ with $\left[\mathrm{H}^{+}\right]$. 
Based on the above discussion, an inner-sphere mechanism was proposed for the oxidation of $\left[\mathrm{Co}(\mathrm{L})(\mathrm{Ac})\left(\mathrm{H}_{2} \mathrm{O}\right)_{2}\right]$ by NBS through the formation of the initial cobalt (III) products owing to,

1 - NBS is capable of coordination of the metal ion through the carbonyl group ${ }^{(15)}$ to form the precursor intermediate.

2- Polymerization of acrylonitrile indicates that, the formation of initial $\mathrm{Co}$ (III) products which were slowly converted to the final $\mathrm{Co}(\mathrm{III})$.

The conjugate base of the complex, $\left[\mathrm{Co}(\mathrm{L})(\mathrm{Ac})\left(\mathrm{H}_{2} \mathrm{O}\right)(\mathrm{OH})\right]^{-}$was considered as the main reactive than its conjugate acid where the hydroxo- group acts as bridge through which the electron transfere takes place. Also, the coordinated $\mathrm{H}_{2} \mathrm{O}$ in the complex, $\left[\mathrm{Co}(\mathrm{L})(\mathrm{Ac})\left(\mathrm{H}_{2} \mathrm{O}\right)_{2}\right]$ seem to be labile and its replacement by NBS perior to the electron transfere is likely. The initial cobalt (III) products may be converted into the final cobalt (III) thus:

$$
\begin{aligned}
& {\left[\mathrm{R}^{\cdot}-\mathrm{Co}^{\mathrm{III}}(\mathrm{L})(\mathrm{Ac})\left(\mathrm{H}_{2} \mathrm{O}\right)\right]^{+} \rightleftharpoons \quad\left[\mathrm{Co}^{\mathrm{III}}(\mathrm{L})(\mathrm{Ac})\left(\mathrm{H}_{2} \mathrm{O}\right)\right]^{+}+\mathrm{R}^{\cdot}} \\
& {\left[\mathrm{R}^{\cdot}-\mathrm{Co}^{\mathrm{III}}(\mathrm{L})(\mathrm{Ac})(\mathrm{OH})\left(\mathrm{H}_{2} \mathrm{O}\right)\right] \rightleftharpoons\left[\mathrm{Co}^{\mathrm{III}}(\mathrm{L})(\mathrm{Ac})(\mathrm{OH})\left(\mathrm{H}_{2} \mathrm{O}\right)\right]+\mathrm{R}^{\cdot}}
\end{aligned}
$$

The presence of succinimide radical $\left(\mathrm{R}^{\circ}\right)$ which was produced by the conversion of the initial cobal (III) into the final cobalt (III) products, was confirmed by the polymerization of acrylonitrile. The succinimide radical may be preferd to abstract hydrogen atom from the medium to form succinimide rather than dimerize to give bisuccinimide ${ }^{(16,17)}$.

\section{Conclusion}

The structure of N-(2-hydroxobenzylidene)-5-phenylthiazol-2-amine Schiff base and its cobalt(II) complex were elucidated using the elemental and spectroscopic analysis. $\mathrm{Co}\left(\mathrm{CH}_{3} \mathrm{COO}\right)_{2} \cdot 4 \mathrm{H}_{2} \mathrm{O}$ as a salt of cobalt (II) was used to prepare the acetato-diaqua-(2-hydroxobenzy-lidene)-5-phenylthiazol-2-aminocobalt (II) complex which has the formula, $\left[\mathrm{Co}(\mathrm{L})\left(\mathrm{CH}_{3} \mathrm{COO}\right)\left(\mathrm{H}_{2} \mathrm{O}\right)_{2}\right]$ in which $\mathrm{Co}(\mathrm{II})$ is hexacoordinated. The kinetic of oxidation of this complex in aqueous media by N-bromosuccinimide has been studied spectrophotometrically. The rate of reaction was first order depending on both reactants and increased with $\mathrm{pH}$,[complex],[NBS] and temperature. The deprotonated form, $\left[\mathrm{Co}(\mathrm{L})\left(\mathrm{CH}_{3} \mathrm{COO}\right)\right.$ $\left.\left(\mathrm{H}_{2} \mathrm{O}\right)(\mathrm{OH})\right]^{-}$was considered as more reactive than its conjugate acid. An innersphere mechanism through the formation of the initial $\mathrm{Co}$ (III) products confirmed by the polymerization of acrylonitrile was proposed. Thermodynamic activation parameters in addition to the rate constant were calculated.

\section{References}

1. Ewais, H.A., Ahmed E.A. and Abdel-Khalek, A.A., Kinetics and mechanism of oxidation of a ternary complex involving dipicolinato- chromium (III) and DLaspartic acid by $N$-bromosuccinimide. Inter. Journal of Chemical Kinetics, 36 (7), 394 (2004).

Egypt. J. Chem. 55, No.2 (2012) 
2. Ewais, H.A., Nagdy, M.A. and Abdel-Khalek, A.A., Kinetics and mechanism of oxidation of the binary and ternary complexes of chromimum (III) involving inosine and glycine by N-bromosuccinimide. Journal of Coord. Chem. 60 (22), 2471 (2007).

3. Abdel-Hady, A.E.D.M., Kinetics of oxidation of N, N-bis (salicylaldehyde-1,2diaminoethane) cobalt(II) complex by periodate. Evidence for the inhibiting effect of copper (II). Transition Met. Chem. 33 (7), 887(2008).

4. Abdel-Khalek, A.A. and Khaled, E.S.H., Kinetics and mechanism of oxidation of (ethylenediaminediacetato) chromium(III) by N- bromosucc- inimide. Transition Met.Chem. 24 (2), 189 (1999).

5. Abdel-Khalek, A.A., Abo-Elhana, S.H. and Hassan, H.M., Inner-sphere oxidation of ternary imino -diacetato chromium (III) complex involving succinate, by NBS. $J$. Appli. Sci. Research, 6 (11), 1837 (2010).

6. Abdel-Khalek, A.A., Ewais, H.A., Khaled, E.S.H. and Abdel-Hamied, A., Kinetics and mechanism of the oxidation of a ternary complex involving nitrilotriacetatocobaltate (II) and malonic acid by $\mathrm{N}$-bromosuccinimide. Transition Met. Chem. 29 (1), 7 (2004).

7. Abdel-Khalek, A.A., Ewais, H.A., Khaled, E.S.H., and Abdel- Hamied, A., Kinetics and mechanism of the oxidation of a ternary complex involving nitrilotriacetatocobaltate (II) and succinic acid by $\mathrm{N}$-bromosuccinimide. Transition Met. Chem. 28 (6), 635(2003).

8. Abdel Hady, A.E.D.M. and Al-Shihri, A.S.M., Inner-sphere oxidation of 2aminomethylepyridine cobalt(II) complex by N-bromosuccinimide. Transition Met. Chem. 26, 417-422 (2001).

9. Farag, R.S., Aly, R.O. and Hassan, M.M., Spectroscopic studies of some Schiffbase drug complexes. Ph.D. Thesis, Al-Azhar Univ., Cairo, Egypt (2010).

10. Singieton, F.G. and Pollard, C.B., Reactions of aldehydes with amines. I. with oaminophenol. J. Am. Chem. Soc. 62 (9), 2288 (1940).

11. Hewitt, W. and Vincent, S., Academic Press INC. New York. (1989).

12. Weaver, M.J. and Yee, E.L., Activation parameters for homogeneous outer-sphere electron transfer reactions. Inorg. Chem. 19,1936 (1980).

13. Mushran, S.P., Pandy, L. and Singh, K., Mechanism of oxidation of some substituted acetophenones by N-bromosuccininmide in acidic media. Monatsh Chem. 111 (5), 1135 (1980).

14. Singh, B., Pandy, L., Sharma, J. and Pandt, S.M., Mechanism of oxidation of some aliphatic ketones by N-bromosuccinimide in acidic media. Tetrahedron, 38 (1),169 (1982).

15. Varaprasad, D.V.P.R. and Mahadevan,V., Aqueous redox polymerization of acrylonitrile initiated by systems based on tervalent and tetravalent vanadium in combination with $\mathrm{N}$-bromosuccinimide as the oxidant. J. Macromol. Sci. Chem. A19 (5), 781 (1983). 
16. Hedaya, E., Hinman, R.L. and Kibler, L.M., Stability of the succ- inimidyl radical. Decomposition of $t$-butyl succinimidepercarboxylate. J. Am .Chem. Soc. 86 (13), 2727 (1964).

17. Koenig, T. and Brever, W., The thermal decomposition of $t$-butyl 2, 5-dioxo-1pyrrolidineperformate. J. Am. Chem. Soc. 86 (13), 2728 (1964).

تمت در اسة كينيتيكية أكسدة منر اكب أسيتات ثنائى اكو -2-هيدروكسو بنزيلدين-5-

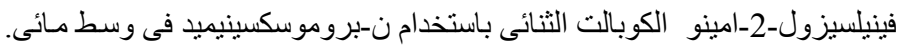

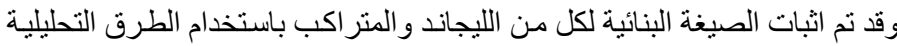

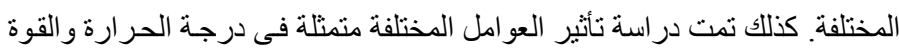

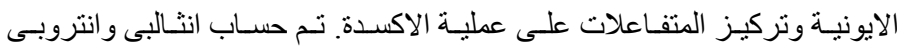

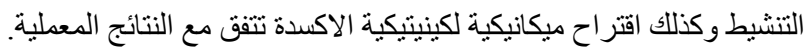

